\title{
EFFECTS OF PARTIAL REPLACEMENT OF DIETARY SOYBEAN MEAL BY AUTOCLAVED GUAR MEAL WITH OR WITHOUT SUPPLEMENTATION OF B - MANNANASE ON GROWTH PERFORMANCE OF NILE TILAPIA (Oreochromis Niloticus) El-Sherbiny, M. A.; M. Amal and A. H. M. Gomaa \\ Rgional Center for Food \& Feed, Agriculture Research Center, 9 El- Gamaa St., Giza, Egypt
}

\begin{abstract}
A growth trial was conducted to evaluate the effects of replacing 5 or $15 \%$ of soybean meal with raw Guar meal, autoclaved Guar meal or autoclaved Guar meal supplemented the diet with $\beta$-mannanase $(0.04 \%)$ on both growth performance and histological status of Nile tilapia fingerlings. Seven iso-nitrogenous ( $\sim 32 \%$ crude protein) and iso-energetic ( $3450 \mathrm{Kcal}$ estimated digestible energy) were formulated. Each diet was randomly allocated to duplicate groups of fish in fiberglass tanks and each tank was stocked with 25 fingerlings (initial average body weight $1.98 \pm 0.47 \mathrm{~g}$ ). Fish were hand fed the experimental diets four times per day for 60 days. For histopathological examination samples of small intestine were taken from fish in different groups. There was significant reduction in growth performance when fish fed diets containing raw Guar meal comparing to those fed the control diet (free of Guar meal). Irrespective of treatment, there were no significant differences in term of growth performance between groups of fish fed diets containing Guar meal with either $5 \%$ or $15 \%$ inclusion level except in term of weight gain.

Irrespective of inclusion levels, better performance of fish were observed when fish fed on control diet (diet 1) or diets supplemented with $\beta$-mannanase and contained autoclaved Guar meal followed by those fed autoclaved Guar meal without enzyme supplementation, while the worst performance was observed by groups of fish fed diets containing raw Guar meal.

Histopathological study showed that feeding fish diet contained $15 \%$ raw Guar meal caused necrosis of the lining mucosa of the small intestine accompanied with infiltration of the inflammatory cells, this status was improved when fish fed diets contained autoclaved Guar meal and more improvement (increase in the number of goblet cells) in intestinal status was observed in group of fish fed diet supplemented with $0.04 \% \beta$-mannanase and contained $15 \%$ autoclaved Guar meal.

Through an economic standing point although, the relative economical efficiency for using Guar meal supplemented with enzyme is compatible with control diet containing soy bean meal, yet in term of net revenue (LE) it is clear that the diet free of Guar meal is still better to be used than any of the diets containing Guar meal.

However, at the same time and through the results of this study, supplementing tilapia diets contained autoclaved Guar meal up to $15 \%$ with $\beta$ mannanase may be considered as a reliable dietary protein source.
\end{abstract}

Keywords: Soybean meal, Guar meal, autoclaved, $\beta$-mannanase, Nile Tilapia

\section{INTRODUCTION}

Aquaculture is the fastest growing animal production sector in the world since 1984. Today, according to the newly released data, world 
aquaculture production of food fish reached 62.7 million tones in 2011 contributes by about $40.1 \%$ of this production (FAO, 2013).To sustain the high rates of increase of aquaculture production, there should be a matching increase in the levels of production of fish feed.

Feed cost is the largest production cost for commercial aquaculture; it reaches at least $50 \%$ of production costs (Hossain et al., 2001). The most expensive ingredients in fish diets are those used as a protein source. As a result, there is a continuous research for alternative protein sources for aqua feed. This was strongly recommended by the Second International Symposium on Sustainable Aquaculture (1997) in Oslo, Norway (Anonymus, 1998) .

Guar meal, a by-product that results from the extraction of Guar gum from Guar beans. Its protein content with excellent amino acid profile varies between $35-45 \%$ depending on the ratio between germ and hull (Nagpal et al., 1971).

Due to this high protein content, using Guar meal as a partial replace soybean meal in farm animal diets might be a useful strategy for decreasing feed costs.

However, previous studies reported that negative effects of adding Guar meal on body weight and feed conversion ratio may be attributed to the presence of anti-nutritional compounds in Guar meal such as trypsin inhibitor, excusive Guar gum, saponin or some other unknown toxic substances. The presence of about $14-18 \%$ residual gum (Anderson and Warnick, 1964 and Nagpal et al., 1971) in Guar meal was proved to be the main source of growth depression in poultry (Hassan et al., 2013).

Guar gum contain $78 \%$ non starch polysaccharide, $90 \%$ of this non starch polysaccharide (NSP) is Beta galactomannan (AGRlaccess, 2001).Due to that, about $60 \%$ of Guar meal total sugar and $40 \%$ of its protein are bound (AGRlaccess, 2001).

In addition, the residual gum, due to its sticky nature, increases intestinal viscosity and decreases nutrient absorption from the small intestine (Salih et al., 1991 and Lee et al., 2003). According to Al- Hafedh and Siddiqui (1998) Guar seed could replace up to $50 \%$ fish meal protein without any adverse effects on growth and feed conversion in Nile tilapia (Oreochromis niloticus).

Patel and McGinnis (1985) stated that, using from 10 to $15 \%$ autoclaved Guar meal in broiler diets has increased growth and feed efficiency compared with birds fed raw Guar meal. Also, they stated that dry heating at $150^{\circ} \mathrm{C}$ for $6 \mathrm{hr}$. or water treatment of Guar meal was not effective in stimulating growth and feed efficiency.

Supplementing diets containing Guar meal for mono gastric animals with enzymes especially mannanase reduced digesta viscosity (Zangiabadi and Torki 2010 and Ehsani and Torki, 2010). In the same trend, McNaughton et al. (1998) and Daskiran et al. (2004) stated that supplementing broiler diets containing Guar meal with mannanase helped in improving feed conversion and the growth performance for birds compared with those fed raw Guar meal. 
The aim of the study was to evaluate the effects of partially replacement of soybean meal with raw Guar meal, autoclaved Guar meal and autoclaved Guar meal + supplementing the diet with $\beta$-mannanase on both productive performance and histological status of Nile tilapia fingerlings.

\section{MATERIALS AND METHODS}

\section{Experimental system and fingerlings:}

Nile tilapia fingerling (Oreochromis niloticus), mono sex were brought to Fish Experimental Unit of the Regional Lab for Food and Feed, Agriculture Research Center, Ministry of Agriculture, Giza, Egypt from a fresh water commercial farm in Domiat governorate.

The fish were reared in a static water system composed of 14 fiberglass tanks (of $85 \mathrm{~L}$ water). The tanks were individually aerated from a main compressor and had individual input and output for dechlorinate tap water. Water temperature was about $24 \pm 1^{\circ} \mathrm{C}$. All the experimental treatments were conducted under an artificial photo period equal to natural light/darkness period (12h light: 12hdarkness).

\section{Diet formulation:}

\section{Guar meal}

Guar meal sample of Indian origin was used in this study. The Guar meal was analyzed for Moisture, Crude Protein (CP), Ether Extract (EE), Crude Fibers (CF), ash, Calcium, Phosphorus, Lysine, Methionine and Cystine using standard official methods (AOAC, 2005). A comparison between the determined chemical compositions of Guar meal with that of soybean is shown in Table 1.

Guar meal used in this study was divided into two portions. The first portion was used in raw status representing raw Guar meal. The second portion was autoclaved at $102^{\circ} \mathrm{C}$ for $15 \mathrm{~min}$. according to what have been recommended by Patel and McGinnis (1985). After autoclaving the meal was dried.

Seven experimental diets were formulated to contain $\sim 32 \%$ crude protein and $\sim 3450 \mathrm{kcal}$ estimated digestible energy according to NRC (1993) (Table 1). The control diet was formulated to contain fish meal and soybean meal as the primary protein sources (diet1). Two experimental diets were formulated to replace 5 and $15 \%$ of the soybean meal with raw Guar meal (diets 2 and 3). Another two diets were formulated using autoclaved Guar meal with the previous replacement ratio (diets 4 and 5). The last two diets were formulated as diets 4 and 5 but supplemented with $0.04 \% \beta$ mannanase (Hemicell-HT) (according to the manufacturer recommended dose) (diets 6 and 7).

The proximate analysis, calculated digestible energy, lysine, methionine and cystine of the experimental diets are shown in (Table 2).

\section{Experimental procedure:}

Three hundred and fifty Nile tilapia fingerlings (Oreochromis niloticus) mono sex of mean initial body weight $(1.98 \pm 0.47 \mathrm{~g})$ were randomly distributed on 14 open system 85 liter tanks, where each tank contained 25 
fingerlings. Each two tanks (duplicate) represented an experimental treatment. The first 15 days of the experiment were considered as habituation period and thereafter the growth trials were carried out for 60 days. Diets were randomly assigned to the experimental units. Fish were hand fed the experimental diets at three\% rate of body weight for six days weekly, four times per day (Jauncey and Ross, 1982 and Coche, 1982). Fish were weighed every two weeks.

Growth parameters and nutrient utilization:

Growth and nutrient utilization parameters were monitored and analyzed in terms of feed intake which is equal to amount of feed presented for each tank at rate of $3 \%$ of body weight across the whole experimental period, final body weight (FBW), weight gain (WG), f Histological examination of intestine:

Samples were taken from the small intestine of fish in different groups and fixed in $10 \%$ formalin saline for twenty four hours. Washing was done in tap water then serial dilutions of alcohol (methyl, ethyl and absolute ethyl )were used for dehydration. Specimens

Table (1): Nutrient compositions of corn (estimated) and low tannin sorghum (determined).

\begin{tabular}{lcc}
\hline Item & Guar meal & Soybean meal \\
\hline Moisture\% & 11.30 & 11.30 \\
CP\% & 48.20 & 47.45 \\
Fat\% & 3.38 & 1.80 \\
Fiber\% & 6.73 & 5.41 \\
Ash\% & 5.40 & 6.30 \\
NFE $\%$ & 22.39 & 27.74 \\
GE 2 (kcal/Kg) & 4305 & 4243 \\
Ca\% & 0.22 & 0.44 \\
Total P\% & 0.70 & 0.73 \\
Amino acids: & & \\
Lys\% $\%$ & & 3.73 \\
Meth\% & 1.32 & 0.73 \\
Cys\% & 0.22 & 0.75 \\
\hline
\end{tabular}

${ }^{1}$ NFE = $100-(\%$ moisture + $\%$ protein + \%EE + \%ash + \% Fibre $)$.

${ }^{2} \mathrm{GE}$ Gross energy content was calculated using the values $5.65,4.2$ and $9.45 \mathrm{Kcal} / \mathrm{gm}$ for protein, carbohydrate and lipid, respectively according to Hepher et al. (1983).

were cleared in xylene and embedded in paraffin at 56 degree in hot air oven for twenty four eed conversion ratio (FCR), specific growth rate (SGR) and protein efficiency ratio (PER). hours. Paraffin bees wax tissue blocks were prepared for sectioning at 4 microns thickness. The obtained tissue sections were collected on glass slides, deparaffinized and stained by hematoxylin and eosin stain for routine examination. (Bancroft and Stevens,1996). 
Table (2):The formulation and chemical composition of the experimental diets (\%).

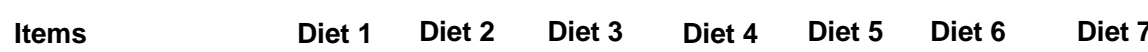

\begin{tabular}{|c|c|c|c|c|c|c|c|}
\hline Fish meal $60 \%$ (FM) & 12.00 & 12.00 & 12.00 & 12.00 & 12.00 & 12.00 & 12.00 \\
\hline Guar meal & & 5.00 & 15.00 & 5.00 & 15.00 & 5.00 & 15.00 \\
\hline Soybean meal $48 \%$ & 43.00 & 38.00 & 28.00 & 38.00 & 28.00 & 38.00 & 28.00 \\
\hline Ground yellow corn & 18.40 & 18.40 & 18.40 & 18.40 & 18.40 & 18.40 & 18.40 \\
\hline Wheat bran & 8.50 & 8.50 & 8.50 & 8.50 & 8.50 & 8.50 & 8.50 \\
\hline Corn starch & 9.00 & 9.00 & 9.00 & 9.00 & 9.00 & 8.96 & 8.96 \\
\hline $\begin{array}{l}\text { Ground mung bean } \\
\text { seeds }\end{array}$ & 5.00 & 5.00 & 5.00 & 5.00 & 5.00 & 5.00 & 5.00 \\
\hline $\begin{array}{l}\text { Monocalcium } \\
\text { phosphate }\end{array}$ & 2.50 & 2.50 & 2.50 & 2.50 & 2.50 & 2.50 & 2.50 \\
\hline Enzyme & & & & & & 0.04 & 0.04 \\
\hline Vit. \& min. mix & 1.60 & 1.60 & 1.60 & 1.60 & 1.60 & 1.60 & 1.60 \\
\hline Total & 100 & 100 & 100 & 100 & 100 & 100 & 100 \\
\hline \multicolumn{8}{|c|}{ Determined chemical composition, calculated digestible energy and protein energy rati } \\
\hline Dry matter (\%) & 92.40 & 92.20 & 92.10 & 92.10 & 92.60 & 92.00 & 92.48 \\
\hline Crude protein (\%) & 32.50 & 32.40 & 32.80 & 32.50 & 32.35 & 32.30 & 32.20 \\
\hline Ether extract (\%) & 1.58 & 2.05 & 2.32 & 2.13 & 2.28 & 2.39 & 2.84 \\
\hline Crude fiber (\%) & 3.08 & 3.41 & 3.90 & 3.31 & 3.22 & 3.06 & 3.09 \\
\hline Ash (\%) & 8.02 & 8.72 & 8.30 & 8.96 & 8.08 & 8.31 & 8.00 \\
\hline NFE $(\%)^{1}$ & 47.22 & 45.62 & 44.78 & 45.20 & 46.67 & 45.94 & 46.35 \\
\hline Digestible & & & & & & & \\
\hline$(\mathrm{kcal} / \mathrm{kg})^{2}$ & 3494 & 3467 & 3476 & 3462 & 3528 & 3506 & 3558 \\
\hline Total phos. (\%) & 1.36 & 1.39 & 1.37 & 1.39 & 1.37 & 1.39 & 1.37 \\
\hline Calcium (\%) & 1.35 & 1.33 & 1.35 & 1.33 & 1.35 & 1.33 & 1.35 \\
\hline Lysine & 2.09 & 1.76 & 1.75 & 1.76 & 1.75 & 1.76 & 1.75 \\
\hline Methionine & 0.60 & 0.57 & 0.52 & 0.57 & 0.52 & 0.57 & 0.52 \\
\hline Cystine & 0.69 & 0.65 & 0.57 & 0.65 & 0.57 & 0.65 & 0.57 \\
\hline Protein energy ratio & & & & & & & \\
\hline$(\mathrm{mg} / \mathrm{kcal})^{3}$ & 93.02 & 93.45 & 94.36 & 93.90 & 91.70 & 92.13 & 90.50 \\
\hline
\end{tabular}

1 NFE = 100 - (\% moisture + \% protein + \%EE + \%ash + \% fiber $)$.

2 Digestible energy was calculated using the values $4.5,4$ and $9 \mathrm{kcal} / \mathrm{g}$ for protein, carbohydrate and lipid, respectively according to Wang et al. (1985).

3 Protein energy ratio $(P / E$ ratio) = crude protein x 10000 / digestible energy, according to Hepher et al.(1983).

\section{Economical evaluation}

The use of raw Guar meal, autoclaved Guar meal and autoclaved Guar meal supplemented with $\beta$ - mannanase in Tilapia diets have been economically evaluated to measure the impact of such practice on the performance efficiency.

The following equations were used to calculate net revenue, economical efficiency and relative economical efficiency of various experimental diets.

Net revenue $=$ Total income $($ L.E. $)-$ Total feed cost (L.E.) 
Total income $($ L.E. $)=$ Total final fish weight $\mathrm{Kg}$ * price of one $\mathrm{Kg}$ of fish (L.E.)

Total feed cost $=$ Total amount of feed consumed $\mathrm{Kg}$ * price of one $\mathrm{Kg}$ diet (L.E.).

Economic efficiency $=$ Net revenue (L.E.) $/$ Total feed cost

Relative economical efficiency $=$ calculated as a percentage from the economical efficiency of the control diet.

\section{Statistical analysis:}

The data obtained were subjected to a two way analysis of variance using the linear model (GLM) of SAS (SAS Institute, 1991). Means were compared using Duncan's new multiple range test (Duncan, 1955).

\section{RESULTS}

The proximate analysis (Table 1) of both of Guar meal and soya bean meal indicated that both of them have nearly the same chemical composition. This gave a preminarly indication that it could be possible to use Guar meal to replace soya bean in tilapia diets.

Initial body weights of fish used in present study (Table 3) were slightly different among the different treatments. However, those differences were not significant $(P>0.05)$.

Replacing dietary soybean by either $5 \%$ or $15 \%$ raw Guar meal (diets 2 or 3$)$ significantly reduced $(P<0.05)$ growth performance of fish comparing to those fed the diet that contain no Guar meal (diet1). Growth of fish fed on either diet contained $5 \%$ raw Guar meal (diet 2) or diet contained $15 \%$ raw Guar meal (diet 3 ) was significantly difference $(\mathrm{P}<0.05)$ only in term of weight gain while there was no difference $(P>0.05)$ in the other parameters .

Fish fed on diets contained $5 \%$ autoclaved Guar (diet 4) or $15 \%$ autoclaved Guar meal (diet 5 ) had better growth rate than those fed diets contained $15 \%$ raw Guar meal. However, this improvement in fish growth did not bring the growth of fish to a growth level similar to that of fish fed on a diet contained no Guar meal (diet 1). Fish fed on diets supplemented by $0.04 \%$ $\beta$-mannanase and contained either 5\% autoclaved Guar meal (diet 6) or 15\% autoclaved Guar meal (diet 7) had growth performance with no significant difference $(P>0.05)$ from those fed the control diet (diet1).

No significant differences $(P>0.05)$ for feed conversion ratio and protein efficiency ratio were observed between fish fed the control diet (diet1) and fish fed a diet contained 5\% raw Guar meal (diet 2). However, FCR significantly increased $(P<0.05)$ and $P E R$ significantly decreased when fish fed a diet contained 15\% raw Guar meal. Replacing SBM by 5\% autoclaved Guar meal (diets 4 ) and $5 \%$ or $15 \%$ autoclaved Guar meal supplemented with $\beta$-mannanase (diets 6 or 7 ) resulted in significantly better FCR and PER values compared to those of diets 2, 3 and 5 .

Irrespective of inclusion levels, better performance of fish were observed when fish fed on control diet (diet 1) or diets supplemented with $\beta$ mannanase and contained autoclaved Guar meal followed by those fed 
autoclaved Guar meal without enzyme supplementation while the worst was for those fed raw Guar meal.

The result obtained from the histopathological study showed that using 5\% raw Guar meal (Fig. 2) caused normal appearance of intestinal histopathology while using $15 \%$ of raw Guar meal (Fig. 3) caused necrosis of the lining mucosa accompanied with infiltration of inflammatory cells.

The use of $5 \%$ autoclaved Guar meal (Fig. 4) caused appearance of goblet cells. Using 15\% autoclaved Guar meal fig. 5 prevented necrotic effect on the mucosa in spite of the presence of inflammatory cells. On the other hand diets contained autoclaved Guar meal together with $\beta$-mannanase (Fig. 6 and 7) showed the greatest beneficial effect on the intestinal structure as diffuse goblet cells were noticed at $5 \%$ autoclaved Guar meal with $\beta$ mannanase while increased number of goblet cells in the presence of inflammatory cells infiltration were noticed at $15 \%$ autoclaved Guar meal with $\beta$-mannanase.

Table (3): Effect of partial replacement for SBM with raw, autoclaved Guar meal and autoclaved Guar meal with the diet supplemented with $\beta$-mannanase on tilapia growth performance ${ }^{1}$.

\begin{tabular}{|c|c|c|c|c|c|c|c|c|}
\hline \multicolumn{2}{|c|}{$\begin{array}{cc}\text { Experimenta } & \% \\
\text { treatments } & \begin{array}{c}\% \\
\text { replacement } \\
\text { of SBM }\end{array}\end{array}$} & $\mathrm{IBW}^{2}$ & $\mathrm{FBW}^{3}$ & $\mathrm{FI}^{4}$ & WG\%5 & $\mathrm{FCR}^{6}$ & PER $^{7}$ & SGR $^{8}$ \\
\hline Control & ----- & $\begin{array}{c}2.45 \\
\pm 0.25\end{array}$ & $\begin{array}{l}8.00^{\mathrm{a}} \\
\pm 0.5\end{array}$ & $\begin{array}{c}10.62^{\mathrm{a}} \\
\pm 0.5\end{array}$ & $\begin{array}{l}5.55^{a} \\
\pm 0.22\end{array}$ & $\begin{array}{l}1.92^{\mathrm{bc}} \\
\pm 0.03\end{array}$ & $\begin{array}{l}1.63^{\mathrm{ab}} \\
\pm 0.04\end{array}$ & $\begin{array}{l}1.18^{\mathrm{a}} \\
\pm 0.03\end{array}$ \\
\hline \multirow{2}{*}{$\begin{array}{l}\text { Raw } \\
\text { meal }\end{array}$} & 5 & $\begin{array}{c}1.86 \\
\pm 0.21\end{array}$ & $\begin{array}{l}5.13^{b c} \\
\pm 0.29\end{array}$ & $\begin{array}{l}6.80^{b} \\
\pm 0.30\end{array}$ & $\begin{array}{l}3.27^{b} \\
\pm 0.16\end{array}$ & $\begin{array}{l}2.08^{a b} \\
\pm 0.11\end{array}$ & $\begin{array}{l}1.50^{b c} \\
\pm 0.08\end{array}$ & $\begin{array}{l}1.02^{c d} \\
\pm 0.06\end{array}$ \\
\hline & 15 & $\begin{array}{c}1.50 \\
\pm 0.20\end{array}$ & $\begin{array}{l}3.79^{\mathrm{C}} \\
\pm 0.25\end{array}$ & $\begin{array}{l}5.14^{\mathrm{b}} \\
\pm 0.35\end{array}$ & $\begin{array}{l}2.29^{C} \\
\pm 0.103\end{array}$ & $\begin{array}{l}2.25^{\mathrm{a}} \\
\pm 0.09\end{array}$ & $\begin{array}{l}1.36^{\mathrm{C}} \\
\pm 0.05\end{array}$ & $\begin{array}{l}0.93^{d} \\
\pm 0.06\end{array}$ \\
\hline \multirow{2}{*}{$\begin{array}{l}\text { Autoclaved } \\
\text { Guar meal }\end{array}$} & 5 & $\begin{array}{c}1.92 \\
\pm 0.40\end{array}$ & $\begin{array}{l}5.83^{b} \\
\pm 0.36\end{array}$ & $\begin{array}{l}7.49^{a b} \\
\pm 0.40\end{array}$ & $\begin{array}{l}3.91^{\mathrm{b}} \\
\pm 0.176\end{array}$ & $\begin{array}{l}1.91^{\mathrm{bc}} \\
\pm 0.04\end{array}$ & $\begin{array}{l}1.62^{a b} \\
\pm 0.03\end{array}$ & $\begin{array}{l}1.12^{\mathrm{abc}} \\
\pm 0.01\end{array}$ \\
\hline & 15 & $\begin{array}{c}2.26 \\
\pm 0.06\end{array}$ & $\begin{array}{l}6.46^{a b} \\
\pm 0.08\end{array}$ & $\begin{array}{l}8.45^{a b} \\
\pm 0.03\end{array}$ & $\begin{array}{l}4.20^{a b} \\
\pm 0.189\end{array}$ & $\begin{array}{l}2.02^{b c} \\
\pm 0.07\end{array}$ & $\begin{array}{l}1.53^{a b} \\
\pm 0.06\end{array}$ & $\begin{array}{l}1.05^{\mathrm{bc}} \\
\pm 0.04\end{array}$ \\
\hline \multirow{2}{*}{$\begin{array}{l}\text { Autoclaved } \\
\text { Guar meal + } \\
\beta- \\
\text { mannanase }\end{array}$} & 5 & $\begin{array}{c}2.18 \\
\pm 0.25\end{array}$ & $\begin{array}{l}6.89^{a b} \\
\pm 0.45\end{array}$ & $\begin{array}{l}8.70^{a b} \\
\pm 0.45\end{array}$ & $\begin{array}{l}4.71^{a b} \\
\pm 0.235\end{array}$ & $\begin{array}{l}1.85^{b c} \\
\pm 0.0\end{array}$ & $\begin{array}{l}1.68^{\mathrm{a}} \\
\pm 0.0\end{array}$ & $\begin{array}{l}1.15^{\mathrm{ab}} \\
\pm 0.0\end{array}$ \\
\hline & 15 & $\begin{array}{c}2.12 \\
\pm 0.27 \\
\end{array}$ & $\begin{array}{l}6.84^{a b} \\
\pm 0.45 \\
\end{array}$ & $\begin{array}{l}8.59^{a b} \\
\pm 0.45\end{array}$ & $\begin{array}{c}4.72^{a b} \\
\pm 0.24 \\
\end{array}$ & $\begin{array}{l}1.82^{\mathrm{C}} \\
\pm 0.02 \\
\end{array}$ & $\begin{array}{l}1.70^{\mathrm{a}} \\
\pm 0.05\end{array}$ & $\begin{array}{l}1.17^{\mathrm{a}} \\
\pm 0.01\end{array}$ \\
\hline
\end{tabular}

1 values are the mean of duplicate groups of fish. Mean values in the same column with different superscripts are significantly different $(P<0.05)$.

2 IBW Initial body weight (g). $\quad{ }^{3}$ FBW Final body weight (g). ${ }^{4}$ FI Feed intake $=(g)$. WG Weight gain= mean final body weight (g)(W1)- mean initial body weight (g) (W0). FCR Feed conversion ratio $(\mathrm{g} / \mathrm{g})=$ feed intake $(\mathrm{g}) /$ weight gain $(\mathrm{g})$.

7 PER Protein efficiency ratio (\%) = Weight gain (g) / Protein intake (g). ${ }^{8}$ SGR Specific growth rate $(\%)=100^{*}$ [Ln final body weight (W1) - Ln initial body weight (W0)] / number of feeding days. 
Table (4) illustrated that the most economical diet was diet1 (control), which gave net revenue 54.5 L.E. followed by diet 753.32 L.E. than Diet 6 51.80L.E. The worst net revenue was presented by diet 3 (containing 15\% raw Guar meal) 28.74 L.E.

The economical efficiency could be used to compare the differences among the experimental treatments. The priority of the diets goes to the more economical ones.

The results showed that diets containing raw Guar meal diet $2(5 \%$ Guar meal) and diet 3 (15\% Guar meal) scored the least feed cost (L.E.) values respectively. While, the highest value (41.50 L.E.) was for the diet free of Guar meal (diet1 control). The best relative economical efficiency (141\%) was for the group fed $15 \%$ autoclaved Guar meal + enzyme supplementation (diet 7) followed by group fed 15\% autoclaved Guar meal diet 5 (135\%).

\section{DISUCSSION}

Inclusion of raw Guar meal instead of soybean meal, in the present study, deleteriously affects measures of growth and feed efficiency at levels of $5 \%$ and $15 \%$. This is supported by the data obtained in (Fig. 3) which demonstrate that using $15 \%$ of raw Guar meal caused necrosis of the lining mucosa accompanied with infiltration of inflammatory cells indicating negative effect on the absorption of the nutrients. Mishra et al. (2013) concluded that replacing SBM with Guar korma at the rate of $2 \%$ in pre-starter and $5 \%$ in starter and finisher diets resulted in poor FCR and inferior performance index score. It is reported that the use of Guar meal in poultry, pig and cattle rations is limited because of its adverse effects on growth rate (Thakur and Pradhan, 1975) and feed intake (Verma and Mcnab, 1982). The depression of growth after feeling chicks was dose related. In contrast, effective replacement of fish meal protein by Guar seed protein up to the level of $50 \%$ is possible in tilapia practical diets without any adverse effects on growth and feed conversion ratio. The growth inhibition that follows the addition of Guar meal in diets may be attributed to the residual gum content of the meal. The residual gum, due to its sticky nature, increases intestinal viscosity and decreases nutrient absorption from the small intestine (Lee etal., 2003). Increasing viscosity of the intestinal contents alters small intestinal structure and intestinal growth (Lee et al., 2005). Mishra et al. (2013) also observed an increase in the length of chicken intestine after they fed a raw Guar meal. They concluded that this change may be due to increasing intestinal viscosity.

The improvement in tilapia growth and feed efficiency measures in the present study (Table 3) after feeding fish on diets contained autoclaved Guar meal may be due to the effect of heat on the removal of anti-nutritional compounds. Patel and Mc Ginnis (1985) also showed that using autoclaved Guar meal in chicks diets improved growth performance. The histopathological data showed that autoclaving of Guar meal caused a marked positive effect on the health of the intestinal villi as using $5 \%$ autoclaved Guar meal (Fig. 4) caused appearance of goblet cells which function is to protect the intestinal mucosa by its secretion (mucin). 
Meanwhile, using 15\% autoclaved Guar meal (Fig.5) prevents necrotic effect on the mucosa in spite of the presence of inflammatory cells indicating the beneficial effect of such treatment._Kleessen et al. (2003), reported that non starch polysaccharides interact with protein and glycoprotein's of the epithelial tissue, causing damage to the tissue.

Table (4): Economical efficiency of Nile tilapia (tilapia niloticous) fed the experimental diets.

\begin{tabular}{|c|c|c|c|c|c|c|c|}
\hline Items & Diet 1 & Diet 2 & Diet 3 & Diet 4 & Diet 5 & Diet 6 & Diet 7 \\
\hline $\begin{array}{l}\text { Total amount of feed } \\
\text { consumed }(\mathrm{Kg}) .\end{array}$ & 10.62 & 6.80 & 5.14 & 7.49 & 8.45 & 8.70 & 8.59 \\
\hline $\begin{array}{l}\text { Price of one } \mathrm{Kg} \\
\text { diet (L.E.) }\end{array}$ & 3.90 & 3.50 & 3.31 & 3.50 & 3.31 & 3.55 & 3.35 \\
\hline $\begin{array}{l}\text { Total feed cost } \\
(\text { L.E.E.) }\end{array}$ & 41.50 & 23.80 & 17.01 & 26.22 & 27.97 & 30.90 & 28.78 \\
\hline $\begin{array}{l}\text { Total fish weight } \\
(\mathrm{Kg})\end{array}$ & 8.00 & 5.13 & 3.79 & 5.83 & 6.46 & 6.89 & 6.84 \\
\hline $\begin{array}{l}\text { Price of one } \mathrm{kg} \\
\text { fish (L.E. })^{* *}\end{array}$ & 12.00 & 12.00 & 12.00 & 12.00 & 12.00 & 12.00 & 12.00 \\
\hline Total income (L.E.) & 96.00 & 61.56 & 45.48 & 70.00 & 77.50 & 82.70 & 82.10 \\
\hline Net revenue (L.E.) & 54.50 & 37.76 & 28.47 & 43.78 & 49.53 & 51.80 & 53.32 \\
\hline $\begin{array}{l}\text { Economical } \\
\text { efficiency }\end{array}$ & 131 & 159 & 167 & 167 & 177 & 168 & 185 \\
\hline $\begin{array}{l}\text { Relative } \\
\text { economical } \\
\text { efficiency }(\%)\end{array}$ & 100 & 121 & 127 & 127 & 135 & 128 & 141 \\
\hline
\end{tabular}

* Economic evaluation was calculated depending on the prevailing prices being : price of Diet1,

Diet2, Diet3, Diet4, Diet5, diet6 and diet 7 was 3900, 3508, 3314, 3508, 3314, 3548 and 3354 L.E. respectively,

${ }^{\star *}$ However $\mathrm{Kg}$ of tilapia fish was 12 (LE).

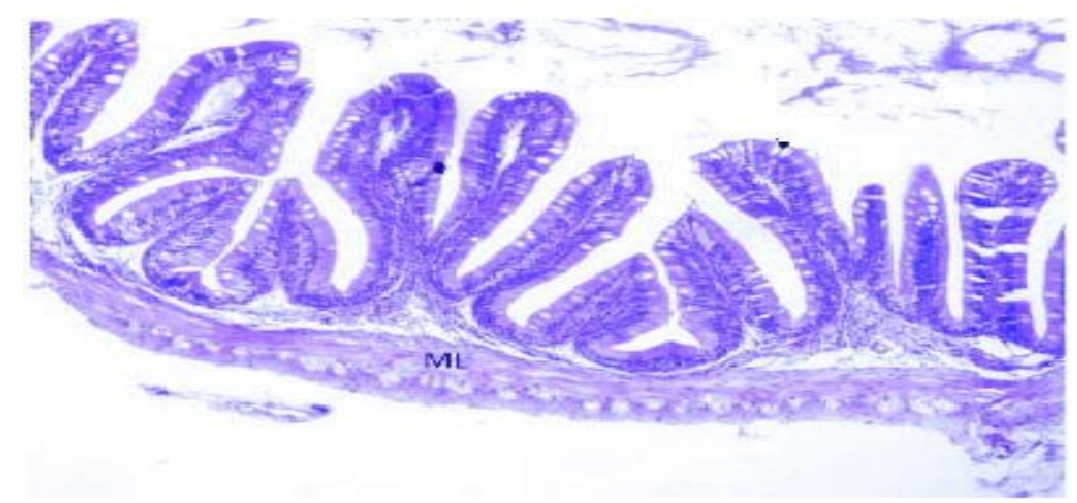

Fig (1): Small intestine of tilapia fed corn-soybean meal diet showed normal appearance, having no morphological characteristics of certain pathologies H\&E X 40 
Fig (2): Intestine of tilapia fed the $5 \%$ raw Guar meal showing normal mucosal lining epithelium with focal inflammatory cells aggregation H\&E X 40

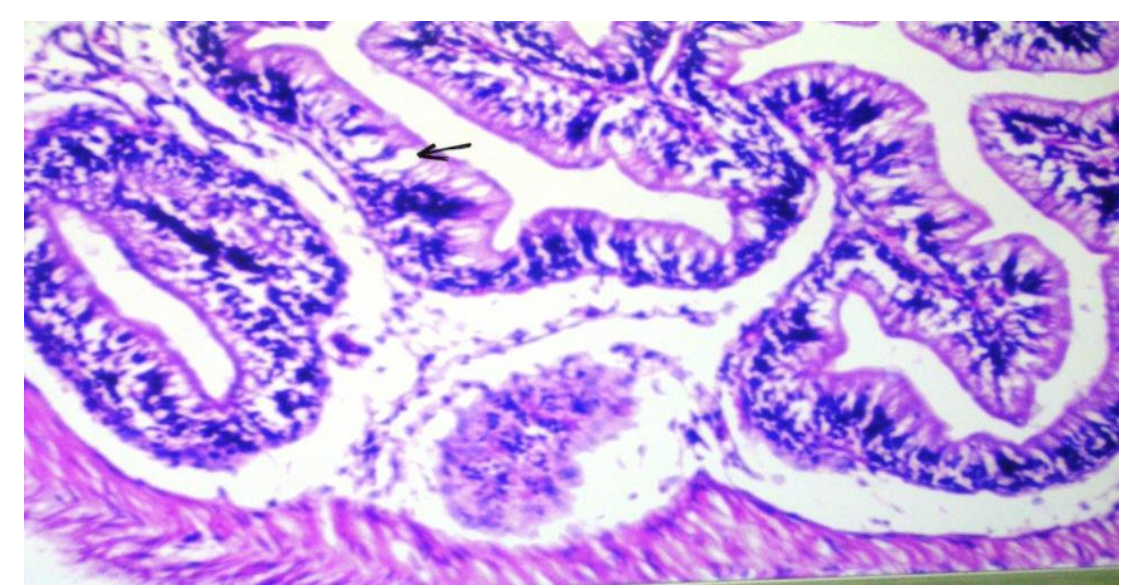

Fig (3): Intestine of tilapia fed the $15 \%$ aw Guar meal showing necrosis of the mucosal layer with inflammatory cells infiltration $H \& E \times 40$ 


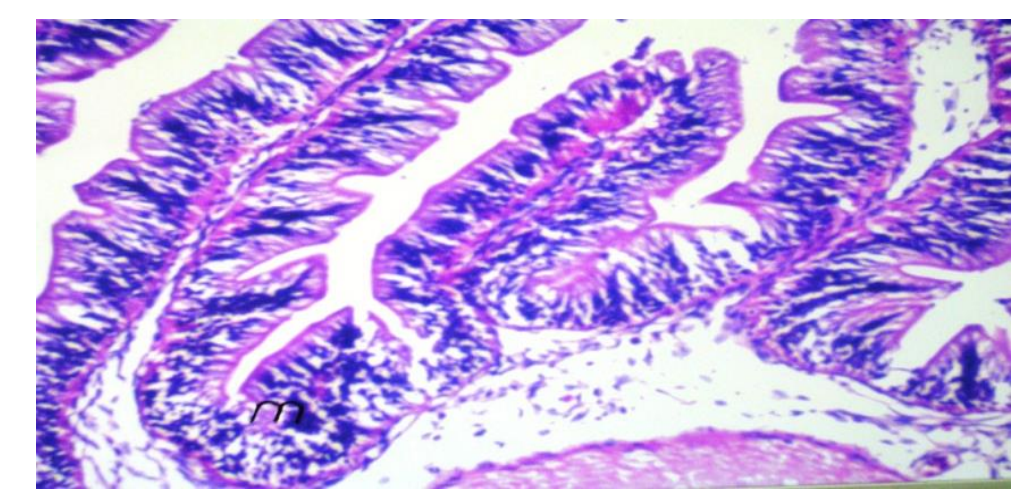

Fig. (4): Intestine of tilapia fed the $5 \%$ Autoclaved Guar meal showing goblet cells formation in the mucosal lining epithelium H\&E X 40

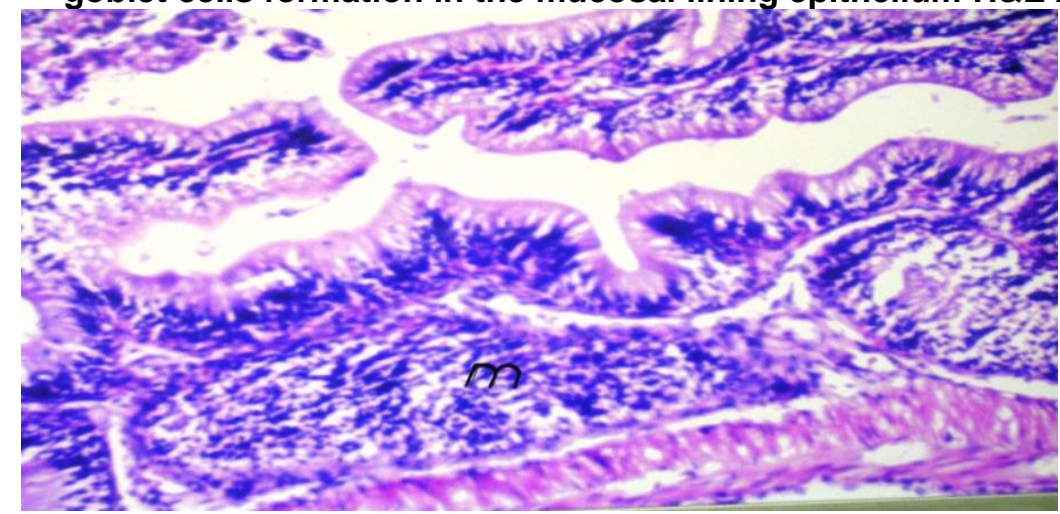

Fig (5): Intestine of tilapia fed the $15 \%$ autoclaved Guar meal showing focal inflammatory cells aggregation was noticed in the lamina propria of the mucosal layer. H\&E X 40 


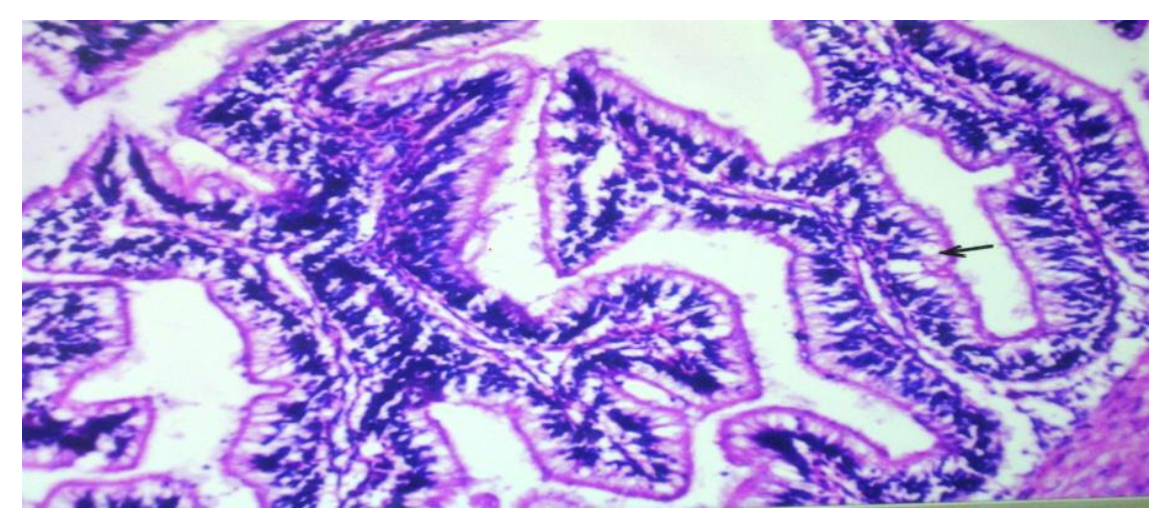

Fig. (6): Intestine of tilapia fed the $5 \%$ autoclaved Guar meal $+\beta$ mannanase showing the lining mucosal epithelium showed diffuse goblet cells formation H\&E X 40

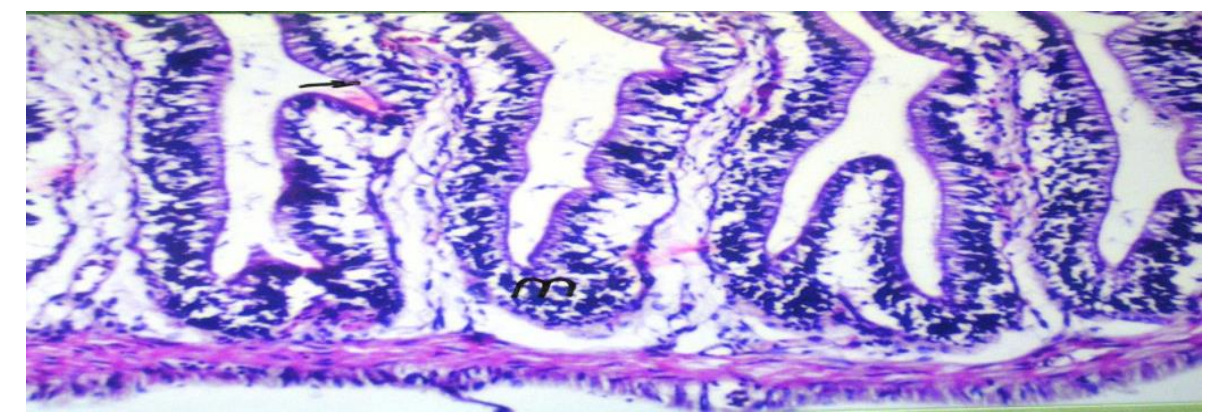

Fig (7) : Intestine of tilapia fed the $15 \%$ autoclaved Guar meal $+\beta$ mannanase showing diffuse goblet cells formation as well as inflammatory cells infiltration $\mathrm{H} \& \mathrm{E} X 40$

Supplementing diets contained $5 \%$ autoclaved Guar meal diet or $15 \%$ autoclaved Guar meal by $\beta$-mannanase showed growth and feed efficiency measures comparable to those of the control diets (Table 3). This is could be supported by the histopathological data in (Fig. 6 and 7) which showed the greatest beneficial effect on the intestinal structure as diffuse goblet cells were noticed indicating the best quality of the absorbing mucosa which was clear in the results of performance parameters . Using 15\% autoclaved Guar meal together with $\beta$ - mannanase caused increased number of goblet cells in the presence of inflammatory cells infiltration. Gharaei et al. (2012) reported that adding $\beta$-mannanase to a diet contained raw Guar gum improve growth and FCR of broilers. Also, Lee et al. (2005) observed that adding $\beta$-mannanase to broiler diets containing $5 \%$ Guar meal significantly improved feed: gain ratio virsus the untreated diets. This may be due to the fact that $\beta$-mannanase is capable of hydrolyzing Guar gum, and 
thereafter decrease the viscosity of the intestinal digesta and finally make the dietary Guar meal more digestible.

Although, the relative economical efficiency of using Guar meal supplemented with enzyme is quit comparable with control diet containing soy bean meal, yet from the net revenue (LE) point of view the diet free of Guar meal is still better to be used then that containing Guar meal. Thus, it could be concluded that using soy bean meal in Nile tilapia diets are still better than using Guar meal.

These results indicated that supplementing tilapia diets contained autoclaved Guar meal up to $15 \%$ with $\beta$-mannanase may be considered as a reliable dietary protein source. Further researches are needed using longer experimental period.

\section{REFERENCES}

AGRlaccess, (2001). NSP Analysis and Digestibility Data.

Al-Hafedh, Y.S. and Siddiqui, A.Q. (1998). Evaluation of Guar seed as a protein source in Nile tilapia, Oreochromis niloticus(L.), practical diets. Aquaculture Research. 29: 703-708.

Anderson, J. O. and Warnick, R. E. (1964). Value of enzyme supplements in rations containing certain legume seed meals or gums. Poult. Sci. 43:1091-1097.

Anonymus (1998). Holmenkollen guide lines for sustainable aquaculture. Proceedings of the Second International Symposium on Sustainable Aquaculture, 2-5 November 1997, Oslo, Univ. of Oslo, Norway.

AOAC (2005). Official methods of analysis. Vol. II. 17 ed. Gaithersburg, MD: Association of Official Analytical Chemists.

Bancroft, J.D. and Stevens, A. (1996). The haematoxylin and eosin. Theory and practice of histological techniques. $4^{\text {th }}$ ed, Ch 6, pp.99-112. Churchill Livingstone, London, NewYork and Tokyo.

Coche, A.G. (1982). Cage culture of tilapias. In: the Biology and Culture of Tilapia, eds. R.S.V. Pullin and R.H. Lowe-McConnel. Manila, Philippines: ICLARM. Cited by Lovell, T. (1989).

Daskiran, M.; Teeter, R. G., Fodge, D. W. and Hsiao, H. Y. (2004) An evaluation of endo- $\beta$-D-mannanase (Hemicell) effects on broiler performance and energy use in diets varying in $\beta$-mannan content. Poultry Science, 83: 662-668.

Duncan, D.B. (1955).Multiple Range and Multiple F Test.Biometrics, 11:1- 42.

Ehsani, M. and Torki, M. (2010). Effects of dietary inclusion of Guar meal supplemented by $\beta$-mannanase on performance of laying hens, egg quality characteristics and diacritical counts of white blood cells. American Journal of Animal and Veterinary Sciences, 5 (4): 237-243.

FAO (Food and Agriculture Organization of the United Nations) (2013). Fisheries and Aquaculture Department. 2013. Information and Statistics Service. FAO, Rome, Italy., http.//wwwFAO.org/Fl/news/GlobalAquacultureProductionStatisticsfis hery/countrysector/FI-CP.EG/3. 
Gharaei, M.A.; Dastar, B.; Nameghi, A.H.; Gholamreza, H.T. and Shargh, M.S. (2012). Effects of Guar meal with and without $\beta$ - mannanase enzyme on performance and immune response of broiler chicks. International Research Journal of Applied and Basic Sciences. 3(5): 2785-2793.

Hassan, S.M.; Al-Yousef, Y.M. and Bailey, C.A. (2013). Effects of Guar bean, Guar meal and Guar gum on productive performance of broiler chicks. Asian J. Poult. Sci. 7: 34-40.

Hepher, B.; Liao, I.C.; Cheng, S.H. and Haseih, C. S. (1983). Food utilization by red tilapia. Effect of diet composition, feeding level and temperature on utilization efficiency for maintenance and growth. Aquaculture, 32: $255-272$.

Hossain, M.A.; Focken, U. and Becker, K. ( 2001). Evaluation of an unconventional legume seed, Sesbania aculeate, as a dietary protein source for common carp, Cyprinus carpio L. Aquaculture, 198: 129140.

Jauncey, K. and Ross, B.R. (1982). "A guide to tilapia feeds and feeding". Institute of Aquaculture, University of Striling. FKA, Scotland, V.K.L., 9: 68.

Kleessen, B.; Hartmann, L. and Baut, M. (2003) Fructans in the diet cause alterations of intestinal mucosal architecture, released mucins and mucosa-associated bifido bacteria in gnotobiotic rats.Br.J.Nutr.89:597-609.

Lee, J. T.; Bailey, C. A. and Cartwright, A. L. (2003) Guar meal germ and hull fractions differently affect growth performance and intestinal viscosity of broiler chickens. Poultry Science, 82: 1589-1595.

Lee, J. T.; Cohnor,S.; Cartwright, A.L. and Bailey,C.(2005). Effects of Guar meal by- product with and without $\beta$-mannanase hemicell on broiler performance. Poult.Sci .84:1261-1267.

McNaughton, J. L.; Hsiao, H.; Anderson, D. and Fodge, D. W. (1998). Corn/soy/fat diets for broilers, $\beta$-mannanase and improved feed conversion. Poult. Sci. 77(Suppl. 1): 153.

Mishra ,A.; Sarkar, S.K.; Ray, S. and Haldar, S.(2013). Effects of partial replacement of soybean meal with roasted Guar korma supplementation of mannanase on performance and carcass traits of commercial broiler chicken. Veterinary world 6(9) : 693-697.

Nagpal, M. L.; Agrawal, O. P. and Bhatia, I. S. (1971). Chemical and biological examination of Guar-meal (Cyampsis tetragonoloba L.). Ind. J. Anim. Sci. 4:283-293.

NRC (1993) National Research Council. Nutrient Requirements of Fish. National Academy Press, Washington D.C., 114pp.

Patel, M.B. and McGinnis, J. (1985).The effect of autoclaving and enzyme supplementation of Guar meal on the performance of chicks and laying hens. Poult. Sci. 64(6): 1148-1156.

Salih, M. E.; Classen, H. L. and Campbell, G. L. (1991). Response of chickens fed on hull-less barley to dietary $\beta$-glucanase at different ages. Animal Feed Science and Technology, 33: 139-149. 27.

SAS (1991). SAS / STAT User's guide. SAS Institute, Cary, NC, USA, 1028. 
Thakur, R. S.and Pradhan K.(1975). A note on inclusion of Guar meal (Gyamopsis tetragonlolba)in broiler rations.Ind.J.Anim.Sci.45:98-102.

Verma, S.V.S. and Mcnab, J.M. (1982). Guar meal in diets for broiler chickens. Br. Poult. Sci. 23:95-105.

Vohra, P.and Kratzer,F.H.(1964).The use of guar meal in chicken rations. Poult. Sci. 43 (2):502-503.

Wang, K.W.; Takeuchi, T. and Watanabe, T. (1985). Optimum protein and digestible energy level in diets for Tilapia nilotica. Bull. Jap. Soc. Sci. Fish, 51: 141-146.

Zangiabadi, H. R. and Torki, M. (2010). The effect of a $\beta$-mannanase-based enzyme on growth performance and humoral immune response of broiler chickens fed diets containing graded levels of whole dates. Tropical Animal Health and Production, 42: 1209-1217.

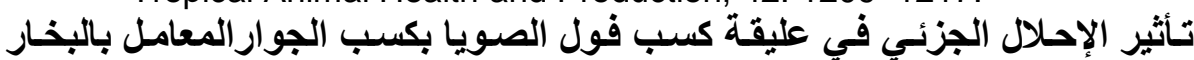

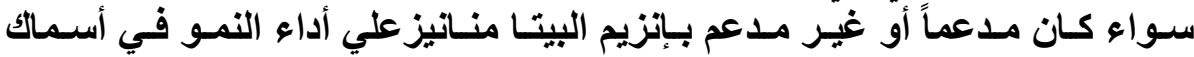

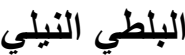

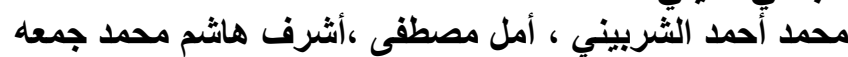

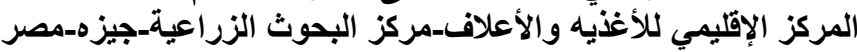

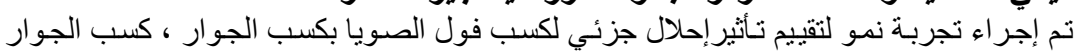

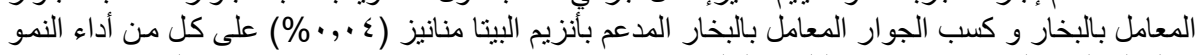

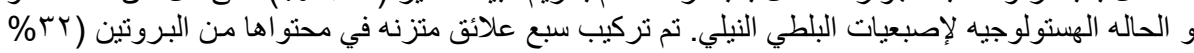



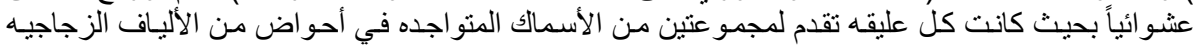

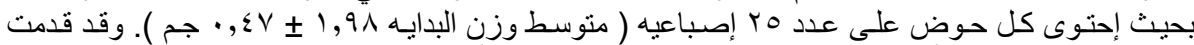

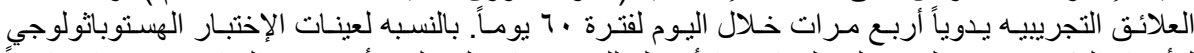

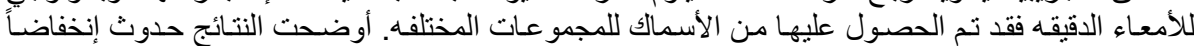

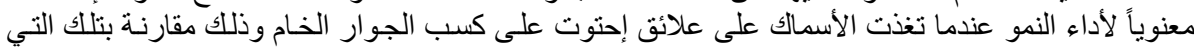

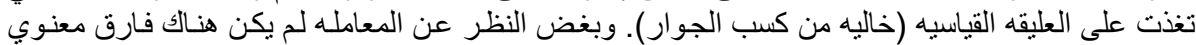

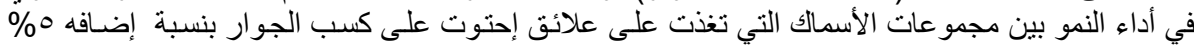

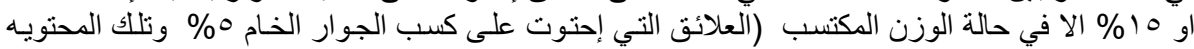
على كسب الجوار الخام 10 (10\%).

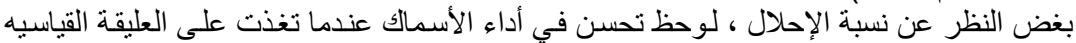

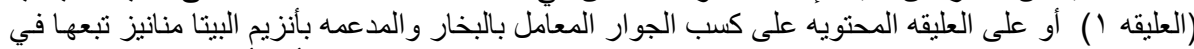

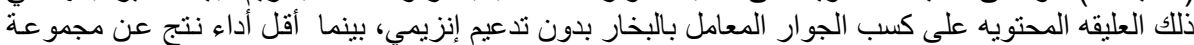

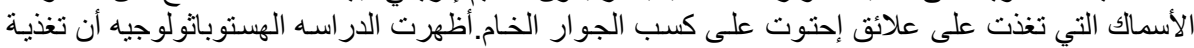

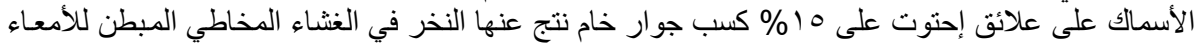

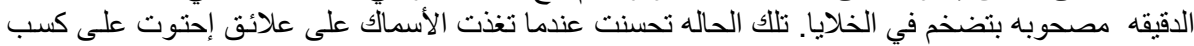

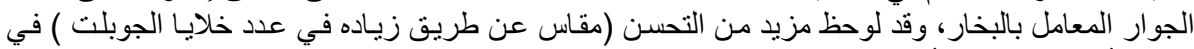

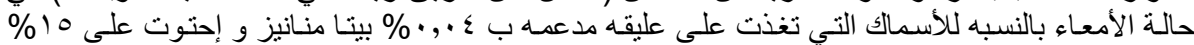

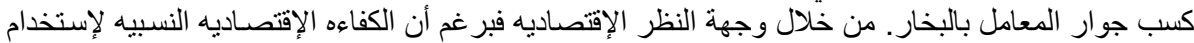

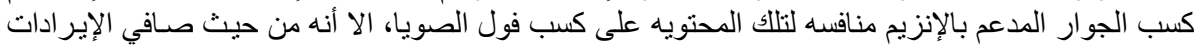

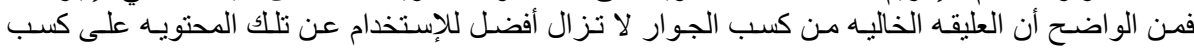

الأ انه وفي نفس الوقت ومن خلال النتائج نجد أن تدعيم علائق اسماك البلطي المحتويه على 10 1 كسب جوار معقم بإنزيم البيتا منانيز يمكن إعتباره مصدر بروتين غذائي. 